\title{
Territorial fragmentation in post-communist Romania: the not so curious case of a de-amalgamation reform
}

\begin{abstract}
The efficiency-driven trend towards amalgamation characterising local government reforms in Europe seems to have escaped Romania, which displays a significant increase in the number of local governments post1989. This is the result of rural first-tier local governments splitting into smaller units. The paper examines objective factors and subjective motivations that have shaped the behaviour of both national and local actors in dealing with territorial reform. First, it explores the rationale and rationality of a central government initiative to facilitate municipal splits against a set of criteria derived from the literature. Second, it examines the municipal splits occurring between 1991 and 2018 against alternative or concurring explanations developed in the literature based on economic, socio-cultural and political elements. The paper argues that in the highly charged political context of the post-communist countries it is reasonable to expect a dominance of subjective rather than objective factors in decision-making on territorial reform.
\end{abstract}

Keywords

Territorial reforms $\cdot$ de-amalgamation $•$ local government $\cdot$ Romania

(C) University of Warsaw - Faculty of Geography and Regional Studies

Introduction

The drive towards more efficiency in local government usually brings into discussion the need to create larger municipalities. In the opposite direction, those in favour of strengthening local democracy are more reserved on the issue of consolidation. Much of the current academic and practical debate is centred on the consolidation (especially amalgamation) of local governments. This is supported by numbers, as in European countries there is still a strong and growing trend towards amalgamation and larger local governments (Steiner et al. 2016). Alongside other countries in the region, Romania has moved towards fragmentation (Kopric 2012; Swianiewicz 2010). Since 1991, when a new democratic constitution paved the way for autonomous local government, there has been a constant increase in the number of local governments (Săgeată 2012). The increase is concentrated particularly in the first half of the 2000s (of 235 splits, 219 occurred between 2002 and 2005), in rural areas (230 out of 235), and more frequently in the eastern and southern parts of the territory (see Appendix). Splits were facilitated (but not mandated) by the central government during the 2000-2004 electoral cycle, with significant delay as compared to the boundary reforms in other countries of the region (see Swianiewicz 2021).

This paper examines the decision-making process and the options faced by both the central government and relevant local actors in relation to these splits of local governments against a normative framework derived from the literature (Dollery et al. 2011; Erlingsson 2005). Thus, it provides an account of the process leading to these splits, without examining their consequences. It aims to answer two questions: Why has the central government
Cristina Stănuș $\mathbb{E}$

Department of International Relations, Political Science and Security Studies, Lucian Blaga University of Sibiu, Sibiu, Romania e-mail: cristina.stanus@ulbsibiu.ro

Received: 29 April 2020 Accepted: 24 July 2020 facilitated these splits? and Why have local actors initiated local government splits?

The following sections review the existing literature on municipal splits, describe the context, and detail the research questions, methodology and data. The rest of the paper examines the political debates leading up to the legal texts that facilitated these splits, the rules set by the central government in its effort to balance support for local democracy with economicadministrative rationality, and the overlapping and mutually reinforcing explanations advanced by local actors seeking approval for a municipal split.

\section{Theoretical background}

The fragmentation-consolidation debate between researchers is skewed towards consolidation. The literature presents amalgamation as the norm, and fragmentation (deamalgamation, splits) as the exception. Amalgamation is seen as the result of a rational approach, superior to the naturally evolved archaic and fragmented structure of the territory (Skaburskis 1992). While in some countries there has been extensive intervention to alter it, in other countries the fragmented structure of local government has been preserved. In some cases, reactions to consolidation reforms led to de-amalgamations. The perceived exceptional nature of these splits/de-amalgamations is reflected in how they are approached in the literature. Thus, they are dominantly analysed in the framework of case studies or small- $n$ studies (Chen 2002; Drew \& Dollery 2014; Erlingsson 2005; Miljan \& Spicer 2015; de Souza et al. 2015), with fewer large-scale studies (see for example Lima \& Silveira Neto 2018; Swianiewicz \& Łukomska 2019). 
From a rational perspective, local government splits/deamalgamations should happen when three conditions are met: the proposed municipality meets required physical and financial criteria, there is public support for the proposal, and the national government is favourable to the idea (Erlingsson 2005). The three conditions are interlinked. It is reasonable to expect that national governments would only grant support to proposals that meet certain conditions and are supported by the affected citizens, while citizens would lend their support to proposals that meet their (nonetheless subjective) criteria. To some extent, this approach sees the national government as a passive actor whose role is to react to proposals coming from local actors. This certainly applies to the small number of cases in the even smaller number of advanced democracies to have been studied in detail. In national contexts where there have been more than a few splits it is reasonable to expect an active rather than passive conduct of the national government.

Researchers have investigated the reasoning behind citizen support. In Canada, citizens aware of a potential increase in expenditure and taxation are less inclined to support deamalgamation (Tanguay \& Wihry 2008), while in Sweden voters in wealthier parts of the municipality are more positively disposed toward secession (Brink 2004). The geographical referential used to assess citizen support is worth noting, as the literature seems to imply it should refer strictly to citizens living in the part of the municipality that wishes to split/de-amalgamate.

Studies of de-amalgamation cases in various contexts have compiled exhaustive lists of objective criteria that could and should be employed to assess the proposals. In Australia these include careful design in relation to economic development patterns, urbanisation and population growth; financial, economic, community and environmental viability of resulting entities aspects; minimisation of transaction and transformation costs; and minimisation of potential sources of conflict (over costs, assets, liabilities and staff) (Dollery et al. 2011; Drew \& Dollery 2014). The Canadian experience adds to these: time passed since amalgamation; and the simplicity of the resultant governance structure in relation to available alternatives (Miljan \& Spicer 2015).

A key question approached in the literature concerns the explanations for the splits/de-amalgamation initiatives. Three overlapping and mutually reinforcing explanations have been advanced: economic, cultural, and political (see Swianiewicz 2021; Erlingsson 2005). Economic explanations are framed in terms of "the secession of the rich", "the subjective feeling of being used" or a "centre-periphery" logic. The cultural explanations emphasise borders not being drawn according to local specificities, the memory of having a separate local government, or the need for proximity between citizens and representatives. The political explanations have been suggested to differ between older (Erlingsson 2005) and newer democracies (Swianiewicz 2021). In older democracies the emphasis is placed on secession potentially favouring a (national) political party. In newer democracies the perception of national government attitudes towards splits and whether an enabling legal framework is in place are emphasised. In Central and Eastern European countries an additional political explanation could be framed alongside the Communist-antiCommunist debate. As communist regimes have conducted rather tough amalgamation reforms, de-amalgamations might be perceived as a natural counter-reaction. Political explanations can also have local rather than national politics as their point of reference. Redrawing boundaries equals a redistribution of political power, with local actors standing to win or lose, which might lead to economic, administrative, social and cultural reasons becoming secondary.

Another topic in the literature concerns the outcomes of splits/de-amalgamations. The focus is on economic, functional, and managerial effects rather than democracy, adding to the wider debate on size and democracy (Erlingsson 2005). Research on this mirrors earlier analyses of the consequences of territorial amalgamation (for a review see Tavares 2018). A study on Poland confirms the importance of scale for administrative costs, but not necessarily for costs of other local services (Swianiewicz \& Łukomska 2019). A study from Brazil finds an increase in capital spending skewed towards the moment of the split, which seems to be smaller in the case of municipalities involved in IMC (Lima \& Silveira Neto 2018).

Literature on local government splits/de-amalgamations is still emergent, particularly that relating to newer democracies. All the aspects discussed above warrant further research. Two of them are particularly suitable for exploration in the case of postcommunist Romania: the active role of central government, and the overlapping and mutually reinforcing explanations behind local initiatives. To contextualise this analysis, there follows a brief overview of some of the features of local government in Romania.

\section{A brief overview of local government in Romania}

First and foremost, Romanian local government is and has always been quite fragmented (see Table 1), although not on the same scale as some other countries in the region. Fragmentation is particularly visible in rural areas, where most of the splits investigated here happened. Throughout the $20^{\text {th }}$ century, successive reforms have reduced the number of communes (rural local governments comprising several villages): from 8,751 in 1936 to 2,706 in 1968 (Săgeată 2012). Communes were historically built as some form of inter-municipal structure (Săgeată 2012), but this character has dissipated through multiple administrative changes associated with the political regimes of $20^{\text {th }}$-century Romania.

Secondly, there is a strong centralist tendency, going back to the uniformisation of local government reforms following the unification of Romanian provinces of different administrative traditions in the inter-war years. This was reinforced under the communist regime. This tendency is still visible in how reforms were conducted in post-communist Romania: emphasis on de-concentration rather than decentralisation reforms (Profiroiu et al. 2017) and partial regionalisation (Dobre 2009). A partial fiscal decentralisation has maintained municipalities' severe dependence on transfers. For example, in 2004, when many of the splits investigated here happened, own revenues (current, capital, quotas of payroll and income tax) accounted for 19.84 percent of the revenues of municipalities.

Thirdly, there is a strong politicisation of local administration, which is associated with strong local leaders (mayors, presidents of county councils) who exercise more power than is legally warranted (Ștefan et al. 2004). This is reinforced by the high level of personalisation present in Romanian politics (Gheorghită 2010). Mayors have thus become important electoral agents for national parties in all types of elections, and national parties have valued obtaining these local elective offices. In order to maximise their presence in local elective offices, national political parties have slowly worked towards excluding other competitors, mainly by introducing electoral thresholds. In time they have become the dominant force in local politics (Stănuş \& Pop 2011).

The centralist tendency and the key role played by local politicians in national political parties set the stage for an interplay of national and local actors and factors shaping debates on administrative and territorial reforms. The following section details the research strategy used to approach these debates.

Research questions, method and data

Below, this paper focuses on the process that led to municipal splits in Romania between 1991 and 2018. It explores 
MISCELLANEA GEOGRAPHICA - REGIONAL STUDIES ON DEVELOPMENT

Vol. 25 • No. 1 - 2021 • pp. 62-70 • ISSN: 2084-6118 • DOI: 10.2478/mgrsd-2020-0044

Table 1. First-tier local governments in Romania, 1925-2019

\begin{tabular}{|c|c|c|c|}
\hline & Key aspects & $\begin{array}{c}\text { Rural local governments } \\
\text { (communes) }\end{array}$ & $\begin{array}{c}\text { Urban local } \\
\text { governments }\end{array}$ \\
\hline $\mathbf{1 9 2 5}$ & Reform for administrative unification of Romanian provinces & 8,751 & 179 \\
\hline $\mathbf{1 9 5 0}$ & $\begin{array}{c}\text { Significant loss of territory in WW2; } \\
\text { Soviet-inspired territorial organisation }\end{array}$ & 4,052 & 236 \\
\hline $\mathbf{1 9 6 8}$ & Reversal to traditional territorial organisation, forced amalgamation & 2,706 & 260 \\
\hline $\mathbf{1 9 9 0}$ & Small scale reforms between 1968 and 1989 & 2,688 & 314 \\
\hline $\mathbf{2 0 0 4}$ & Immediate consequences of 2001 reform allowing voluntary \\
& de-amalgamation & 2,827 & 319 \\
\hline $\mathbf{2 0 1 9}$ & Current situation & 2,862 & \\
\hline
\end{tabular}

Source: Author's own elaboration.

formal explanations provided by, and informal motivations of, actors at two levels of government - the national and the local. The explanations category captures the rational (objective) aspects of the process, while the motivations category captures the subjective viewpoints and opinions of those involved. Two research questions, each detailed in sub-questions, are pursued:

RQ1. Why has the central government facilitated splits of local governments?

How were key aspects of the reform understood and argued about at central government level? What kind of evaluation criteria has the central government employed in this reform? To what extent do they mirror criteria thought relevant in other national contexts (Dollery et al. 2011; Drew \& Dollery 2014) when conducting fragmentation reforms?

RQ2. Why have local actors initiated local government splits?

What types of explanations (economic and administrative, socio-cultural, political, see Swianiewicz 2021; Erlingsson 2005) are formally put forward by local proponents of splits to convince decision-makers? Is a certain type of explanation dominant? Are there other discernible motivations of local actors?

The paper employs a directed qualitative document analysis approach (Hsieh \& Shannon 2005) alongside the above subquestions. The analysis builds on two categories of documents. The first category includes documents reflecting central government policy on the territorial administrative structure: governing programmes, strategies for public sector reform, laws and regulations. The second category covers the official documentation submitted to the parliament to justify a sample of 62 splits. These were approved between 1991 and 2018 via individual parliament acts, hence detailed documentation was available. The typical documentation justifying a split includes a synthetic exposition of arguments, copies of local government decisions concerning the split, copies of documents attesting local referendum results, the viewpoint of the Legislative Council (compliance with existing legal provisions and technicalities), and the opinion of the central government. Data coding focused on responses to the theoretically relevant guiding questions present in the documents. The results are presented and discussed in the following sections.

The national politics of territorial reforms

At national level much of the understanding and debate on territorial reform was guided by the perceived need to reverse the territorial-administrative reforms of the communist era, while navigating ethnic politics and the conditionalities of EU accession.

Territorial reforms have always been a difficult topic in postcommunist Romanian politics due to their association with ethnic politics (Bakk \& Szász 2010; Benedek \& Bajtalan 2015; Bochsler \& Szöcsik 2013; Maxfield 2012). Mainstream political parties have avoided being associated with the territorial reform requests of the Democratic Union of Hungarians in Romania (UMDR-RMDSZ). Debates have centred on decentralisation, local autonomy and regionalisation (Maxfield 2012; Preda \& Soare 2008), with few attempts to mention amalgamation. Moreover, debates on decentralisation and regionalisation have been partially driven by the perceived and actual conditionalities of the EU accession process (Benedek \& Bajtalan 2015; Bochsler \& Szöcsik 2013; Dobre 2009).

After 1989 a significant part of the debate concerning local government in Romania was centred on reverting to a version of the pre-communist territorial-administrative organisation of Romania. Particularly salient in this debate was the heavy-handed 1968 amalgamation reform. Aimed at reversing the 1950 Sovietinspired territorial-administrative structure, the 1968 reform was part of the Romanian regime's move away from the Soviet Union and towards national Communism (Soare 2013). While getting rid of Soviet-inspired legal forms, the 1968 reform was centred on rationalising the lower levels of government, although in a highly centralised system (Săgeată 2011).

The debate concerning the reversal of the 1968 reform was particularly important in early 1990s, when Romania was building a new constitutional framework. It was framed around the necessity to reinstate communes and counties to account for local specificities and increase local autonomy (Băcanu 2010; lordan \& Alexandrescu 1996). Initiatives towards de-amalgamation, particularly focused on the counties (Nistor 2000), were articulated within the party system by a single-issue small political party (Party for the Rebirth of Abusively Abolished Counties, Partidul Renașterii Județelor Abuziv Desființate) and a non-governmental organisation (National League of Abusively Dismantled Counties, Liga Națională a Județelor Abuziv Desființate). Sometimes these entities received funding from local governments. ${ }^{1}$ The political party competed in local elections with limited success. In the 1996 local elections it gained 33 seats (31 in local councils, 1 in a county council and 1 mayor); in 2000 it gained 8 seats (local councils), and after 2004 it virtually disappeared (Preda 2013). The issue found its way into the political and electoral manifestos of major parties (1995 governing programme of the Văcăroiu 
government; point 18 in the Contract with Romania, the 1996 electoral manifesto of the centre-right Democratic Convention; the 2000 electoral manifesto of the social-democrats). The centreright governing coalition of the 1996-2000 electoral cycle actively examined the issue and declined to pursue it, citing worsening economic conditions (Ziarul de lași 1998). More recently, the debate on de-amalgamation has ceded space to a less articulated debate on amalgamation, which often cites the problematic rural municipalities unable to cover expenses from their own revenues (Guvernul României 2016).

Reforms implemented in 2001 under the social-democrat Năstase government enable splits/de-amalgamations. In public discourse this reform is usually referred to as "de-amalgamation", although official documents do not use the term. The government introduces the idea of territorial reform in its 2001-2004 governing programme as part of a set of measures designed to lead to "rational development and modernisation policies for urban and rural localities" (Guvernul României 2001a; Parlamentul României 2000). The target is to set up 1,000 new rural municipalities in order to bring local governments closer to the citizens, without limiting splits/de-amalgamations to specific borders that had at some point existed. The set of measures is designed to prepare EU accession and it also refers to upgrading the status of some rural municipalities to towns. The translation of the political programme into a workable strategy for public administration reform brings an amendment, as an inter-municipal cooperation policy is added to help counterbalance the increased fragmentation (Guvernul României 2001b). The timing of this reform coincides with the third stage of the decentralisation process, when a comprehensive law of local public administration better specifies the functions of local authorities, especially in relation to public service provision (Profiroiu et al. 2017; Profiroiu \& Profiroiu 2006). It seems counterintuitive that a fragmentation reform should be timed to coincide with a significant overhaul of local governments. Looking at this timing differently, it can be said that the dire economic conditions before 2001 did not allow for significant reforms, and hence this overlap.

A political explanation is also plausible. The Social-Democrat Party (PSD), considered the de facto successor of the Communist Party, returns to government after a four-year centre-right government and is keen to prove its democratic credentials and to strengthen its local base. A concession to bottom-up demands for de-amalgamation rejected by the previous government contributes to building the desired democratic credentials. At the same time, given the important electoral role of the mayor, an increase in the number of municipalities may have increased votes for the PSD. At least two elements support the idea that some sort of political calculus was being made. First, at the peak of commune splitting in 2004, the most visible voice of disapproval comes from within the PSD, as the Minister of the Interior points out the significant administrative costs during a parliamentary committee hearing. Second, following the implementation of the first splits, opposition parties repeatedly and formally complain in parliamentary debates that the appointed interim leaders of the newly created local governments belong either to the governing party or to the Hungarian minority party, which gives these two parties an unfair advantage in the first local elections. This political explanation is consistent with what has been observed in other countries in the region regarding regional reforms, namely that political strategies are an important factor in determining institutional outcomes (O'Dwyer 2006; Yoder 2003).

The reform is overall a balancing act, as the national government opens the possibility for splits/de-amalgamations while it tries to ensure some objective criteria are met. Maintaining a certain degree of economic-administrative rationality to the process turns out to be more difficult than expected, due to the divergence of opinion between the PSD cabinet and the PSD- dominated parliament. Before 2001, the parliament exercises its legislative sovereignty and approves a few splits despite the lack of clear criteria. In 2001 the parliament debates and passes, without significant changes, cabinet proposals aimed at strictly regulating splits, as well as a law on local referenda. The cabinet sets in motion an administrative process to centralise all potential splits initiatives and examine them against the objective criteria specified in the legislation (see below). County-level committees created at the instruction of the central government embark upon examining and, in some cases, making proposals and asking municipalities whether they would consider a split. Proposals are then aggregated by the cabinet and submitted to the parliament in two stages, leading to two separate laws approving lists of splits. Individual members of parliament from all parties, including the PSD, bypass this administrative process and promote individual proposals to the parliament. Some of these proposals precede the launch of the county committees, some come after the committees have finished their work, and some do not meet the objective criteria. When asked to give its formal opinion on some of these proposals, the cabinet asks that they be rejected and examined later in a centralised manner. The parliament, with significant support from PSD MPs, nevertheless approves these proposals, including some that did not meet one or more of the objective criteria. The following section discusses the objective criteria employed in assessing de-amalgamation proposals.

\section{The rules for splits/de-amalgamations}

In what follows, the 2001 formal rules for splits/deamalgamations are examined against the set of criteria considered relevant in other national contexts (Dollery et al. 2011; Drew \& Dollery 2014; Miljan \& Spicer 2015). Overall, the government opted for combining moderate evaluation criteria with quite a complicated sequence of procedural steps, effectively stacking the deck against some of the potential local de-amalgamation initiatives. The stringent community support criteria derive from the constitutional text.

Constitutional provisions concerning territorial organisation drafted in 1991-92 maintained the status quo resulted from the 1968 legislation and made these issues subject to organic laws, legal acts requiring a two-thirds majority in both chambers of parliament. These provisions apparently give some margin to the parliamentary majority in what regards territorial reforms. When corroborated with constitutional provisions explicitly protecting local autonomy, they effectively forbid the parliament or cabinet from altering territorial organisation without formal consultation of the affected citizens by referendum. ${ }^{2}$

The procedure for territorial splits is included in the Law on Local Public Administration (Parlamentul României 2001a). ${ }^{3}$ It involves a complicated sequence of steps:

1. a split/de-amalgamation proposal including proof that minimal criteria are met is submitted to the local council of the existing municipality either by the mayor, a group of councillors, or citizens making use of provisions concerning citizens' initiatives. Proofs require certification from the county-level fiscal authorities, county-level statistical office, prefecture (representative of the central government) and county council (second-tier local government). Minimal criteria apply to all municipalities resulting from the split;

2. if the local council approves the proposal, it must set a date and provide funding for a local referendum;

${ }^{2}$ In 1998 Romania ratifies the European Charter of Local Self-Government, which further reinforces this.

${ }^{3}$ Since then there has been only one bottom-up initiated attempt at amalgamation, which has failed due to a lack of community support (see Stănuș 2018). 
3. following legality control by the prefect and the appointment of a judge to oversee it, the local referendum is organised. It is validated if a simple majority of registered voters in the existing municipality attends;

4. if the referendum is successful (a simple majority in favour), relevant documents are forwarded to the Parliament either by having an MP submit a legislative proposal or by asking the cabinet to do so;

5. the Parliament passes a law approving the split with a twothirds majority.

This procedure sets a very high threshold for community support for splits/de-amalgamations. At the same time, it stacks the deck against initiatives by municipalities with low capacity by placing the weight of gathering the required policy evidence on them.

The minimal criteria to be met are formulated in a different legal text (Parlamentul României 2001b) and include, with specific reference to new rural municipalities resulting from a split:

1. a minimal size of 1,500 citizens, as measured at the last census;

2. economic potential to "ensure budgetary balance";

3. existence of rail and/or road links between the proposed administrative centre of the new municipality and the other villages;

4. a reduction in the distance citizens must travel to reach the administrative centre of the municipality;

5. the availability of buildings for local government offices, school, primary medical care facilities or pharmacy, police station, and train or bus station;

6. minimal facilities that need to be available in the administrative centre (post office, sports facilities, cultural centre including library, commercial spaces, places of worship, cemetery, veterinary care services, local fire service, local waste disposal facilities, street water pumps), which can be developed post-split.

These criteria seem very specific, yet they only minimally consider population trends, economic development patterns and the financial, economic and community viability of the resulting local governments. A minimal population size is imposed, but there is no requirement to take population projections into account, despite official acknowledgements of significant depopulation in rural areas. The list of minimal facilities is reflective of the dire state of rural municipalities at that point and, for example, does not include requirements related to water supply and sewage or the quality of rail and road links. The key criterion is economic potential, operationalised as the ability to pay for the resulting costs.

In 2007 a change to the law made the criteria more restrictive, in line with the official plan of the new centre-right government to stop fragmentation, and added several supplementary criteria:

1. measurement of size is based on the most recent official statistics rather than data from the last census;

2. $25 \%$ of the active population must be involved in nonagricultural economic activity;

3. $45 \%$ of houses must have been built after 1960 ;

4. modernised (asphalt, concrete) roads must link the administrative centre and the other villages;

5. all villages splitting must be farther than $5 \mathrm{~km}$ from the current administrative centre;

6. the sum of distances between all villages and the administrative centre should be at least $15 \mathrm{~km}$ less than it was previously.

This raised the threshold in terms of financial, economic and community viability of the resulting municipalities. The threshold for population in non-agricultural activity is a game changer and limits the possibility to initiate splits. In 2005 , on a national level, non-agricultural economic activities occupied $24.5 \%$ of the rural active population of Romania. Moreover, official statistics recorded a constant decrease in the number of non-agricultural jobs in rural areas after 1998 (Ministerul Agriculturii și Dezvoltării Rurale 2008). This effectively blocked further splits/de-amalgamations without formally abolishing the policy. The same legal text binds the upgrade from rural municipality (commune) to town or from town to the higher status municipiu with voluntary amalgamation, which is to be funded partially by the central government. However, no plans were made for the actual implementation of this funding obligation and the provision of support is at the discretion of the current government.

Beyond specifying responsibilities for the transition period, the transformation process and the resulting transaction and transformation costs are not addressed in the initial regulations. During the transition, until local elections can be organised, the prefect appoints two delegates who take charge of the finances of the new local government and communicate on all relevant matters with the officials of the initial local government.

Nor too does the minimisation of potential sources of conflict during de-amalgamation seem to have been considered. Regulations operate on the premise that the municipalities will simply divide assets based on the new boundaries and no significant conflicts will arise if existing infrastructures (mainly water supply and sewage) and debts need to be divided. ${ }^{4}$ A 2006 change to the legal provisions dealt with what had developed into the only real source of conflict, the issue of drawing boundaries. The new rules required that a cadastre plan be attached to the initiative for splits/de-amalgamation and subject to the referendum. Moreover, it was specified that de-amalgamations must involve returning to boundaries that had existed prior to the amalgamation, and procedures for dealing with conflicts were introduced.

The reform operated under the presumption that, given the sometimes abusive nature of the amalgamations conducted by the communist regime, the decades passed since amalgamation should not constitute a hindrance to splits/de-amalgamations. Moreover, in 2001 the local governance structure in Romania was quite simple, as inter-municipal cooperation had not yet been introduced, and hence the simplicity of the resulting governance structure was also not an issue.

The next section of the paper delves into details of how local actors responded to this enabling framework.

\section{Explanations and motivations at the local level}

The explanations put forward to support individual splits/ de-amalgamations generally follow the official list of criteria, and hence include both economic, socio-cultural and political elements. What distinguishes one split from the next is the relative weight of these criteria, the degree of detail, as well as elements additional to the official set of criteria. It must be noted that the narrative parts of the proposals are written, and hence analysed, from the perspective of the part of the municipality that secedes (the part that will group around a new administrative centre, referred to as the "new" municipality), with little reference to the remaining part (the part that will comprise the current administrative centre, referred to as the "remaining" municipality). Very rarely does the proposal give equal narrative space to both the new and the remaining municipality (for example, Horodnic de Sus). In almost all proposals it is specified that they involve

${ }^{4} \mathrm{According}$ to official statistics, in 2001 only 1,383 rural municipalities had water supply infrastructure, 383 had sewage infrastructures, and, in many cases, these did not cover the entire municipality. Total local government debt in Romania in 2001 was only 1.36 million Euro. 
de-amalgamation along pre-1968 borders. Most proposals give significant weight to cultural and political explanations and less to economic ones.

One category of economic explanations employed in these proposals emphasises the need to restore a natural economic development trend that, in local opinions, has been interrupted by the amalgamation reforms. This explanation is invoked in contexts in which we can suspect a "secession of the rich" (for example, Comănești, Sânnicolau Român), as the better-off part of the existing municipality wishes to split, but also in contexts in which it does not seem that a part of the existing municipality is richer than the other. The latter are cases of what we might call a "subjective secession of the rich" (see, for example, Hănțești). The idea of a natural economic potential having gone unfulfilled due to amalgamation is supported in some cases by detailing the history of local economic development going back to the Middle Ages (Chibed, Coșna).

A second category of economic explanations emphasises that the new municipality be economically viable according to official evaluation criteria. Some proposals approach economic criteria in detail, going as far as providing inventories of local shops and small businesses, agricultural land, livestock, farm equipment, etc. to prove economic viability. In all cases analysed, there is less detail when financial viability is approached (in only one of the cases analysed, Sâmbăta de Sus, is a detailed rather than a summary budget sheet provided). This is understandable, as all new and remaining municipalities analysed could only balance their budget (a key criterion in the official list) after receiving transfers from the upper tiers of government.

Secondary economic explanations, which appear rarely, seem to mirror some public choice theoretical arguments advanced in the literature in regard to functional and managerial aspects (Tavares 2018). Thus, some of the proposals cite increases in citizen information about public services (Văcăreni), better feedback to the local government (Gepiu, Roşiori), and better administration of assets (Rafaila, Rădești). In very few cases we also find reference to a subjective feeling of having been left behind by the current administrative centre, either in terms of public services development (Văcăreni) or in efforts to attract investments (Gepiu and Sânnicolau Român).

A widely used category of cultural explanations invokes the historical background of the community. It is very rare that a proposal does not mention the first documentary attestation of the administrative centre of the new municipality. Dates mentioned vary from the 12th to the 19th century, and are usually accompanied by accounts of specific historical events and, sometimes, even by detailed narratives on the religious, cultural and educational importance of the municipality throughout its history (Gepiu, Ploscuteni, Șieu, etc.).

A second category of cultural explanations advances a "futility of resistance" argument, like the one employed in some amalgamation debates (Drew et al. 2019). Like in other communist regimes (see for example Yoder 2003), territorial reforms in Romania aimed at increasing the regime's grip over territory and address ethnic, regional, localist factors. The 1968 reform in some cases went against the theory of the central municipality, as it has sought to undermine localist tendencies and political resistance by forcefully merging highly developed large municipalities with smaller ones and placing the administrative centre in the small locality. All the proposals analysed invoke a version of the "borders-were-not-correctly-drawn" explanation. Reverting to the old borders - to "normality" - and making up for the lost status are necessary and unavoidable and it is futile to oppose this, as locals feel entitled to it and will persistently demand it. The harder the trauma of the amalgamation, the stronger this explanation appears (for example, Fântâna Mare, Titești, Văcăreni).
A third category of cultural explanations, present in some of the cases, focuses on local identity issues. Some proposals mention "strong identity specific to a bound-together community able to conduct its own collective affairs" (Cosna) or the cultural differences between the two parts of the amalgamated municipality (for example, Hăntești, Șinca Nouă): "the two municipalities [amalgamated by the communist regime] are very different in terms of customs, conduct and speech, as they are part of two different geographical areas, Adîncata has influences from Bucovina, while Hănțești is part of the Old Kingdom [preWW1 Romanian Kingdom]". A secondary theme in this category links this identity with a special historical status (Popeşti, Ruginoasa, Văcăreni, Vulcana-Pandele), with references to the past political, administrative, educational and cultural role played by the municipality proposed to be de-amalgamated.

A smaller number of the proposals analysed uses a simpler cultural explanation and mentions the memory of having a separate local government (Ghindăoani, Poiana Ilvei and many others)

The political explanation provided in these proposals is centred on political conflict. The persistent political conflict is distinct, as it sets local actors against an absent foe - the communist regime, whose actions have inflicted harm upon the local community. In very few cases (Văcăreni, Vulcana-Pandele) local contemporary political conflicts between the two parts of the existing municipality are mentioned.

Political strategies and motivations seem to drive these proposals. To the extent that they could be identified, the initiators of the splits are local initiative groups from the new municipality, sometimes placed inside the local council of the existing municipality (Perșinari, Itești, Livezile, Poieni Solca, Bucovăt), sometimes outside it (Sânnicolau Român). Local councillors are particularly well placed to gain superior influence and power in the new municipality (for example, a key member of such a group is the first mayor of the new municipality of Bucovăț). We could not find evidence of a counter-reaction from the current power holders. For example, rather than oppose the proposals, the mayors of the existing municipalities were supportive of the splits proposals and took charge of the entire formal process. Local political actors do not seem to be ideologically motivated. In a few cases of splits in areas with a significant Hungarian population, an ethnic-territorial logic is at play. Some splits are proposed by local party organisations of the Hungarian minority party (Mădăraș). The same party uses its blackmail potential against the sitting government to secure the approval of splits where not all formal conditions were met (Cozmeni).

\section{Conclusion}

This paper has sought to explore in the Romanian context two key aspects of territorial fragmentation reform: the role of the central government and the overlapping and mutually reinforcing explanations behind local initiatives. The analysis has showed that much of the understanding and debate on the topic of territorial reform at national government level was guided by the perceived need to reverse the territorial-administrative reforms of the communist era while navigating ethnic politics and the conditionalities of EU accession. For an electoral cycle and likely due to politico-electoral calculations, the central government has actively pursued fragmentation by combining a new legal framework formally aiming to enhance local democracy with administrative facilitation. A combination of moderate objective criteria for splits/de-amalgamation and a quite complicated sequence of procedural steps has nevertheless led to a significant number of new municipalities. The analysis of documents containing policy evidence in support of a series of splits/deamalgamations indicates a dominance of subjective (cultural and 
political) factors linked in one way or another to the communist era amalgamation reforms and their consequences. Keeping with a key question in the literature (Swianiewicz 2010; Swianiewicz 2018) we may ask if territorial fragmentation was a solution for Romania. When compared to territorial reforms in older democracies a tentative answer is "No." However, if we account for the highly charged political environment, it is understandable that subjective explanations are dominant in territorial-reform decision-making. Hence, we might also advance a tentative "Yes." This analysis contributes two small elements to the wider theoretical debate. In what regards the political elements of splits, it suggests that two layers exist: the formal political explanations advanced in official documents and the sub-textual political motivations and strategies. In what regards central governments, it suggests shifting the viewpoint and assessing their role not as passive respondents to the bottom-up initiatives for splits/deamalgamations but as active and engaged actors.

\section{Acknowledgements}

This work was supported by the Romanian Ministry of Research and Innovation, CNCS - UEFISCDI, grant number PN-III-P1-1.1-MC-2019-0294 and the National Science Centre in Poland, grant number 2017/26/M/HS5/00152. The author wishes to thank Paweł Swianiewicz and the anonymous reviewers for the valuable comments and suggestions and Florin Feșnic for the introduction to Tableau Public.

\section{ORCID}

Cristina Stănuș (10) https://orcid.org/0000-0001-7635-7522

\section{References}

Băcanu, PM 2010, 'Cum ar trebui să arate harta redesenată a României?' ['How should Romania's redrawn map look like?'], România liberă, 11 March. Available from: <https:// romanialibera.ro/opinii/interviuri/cum-ar-trebui-sa-arateharta-redesenata-a-romaniei-179771.html>. [28 March 2020].

Bakk, M \& Szász, AZ 2010, 'Conflict and convergence: Regionalisation plans and autonomy movements in Romania', European and Regional Studies, vol. 1, no. 1, pp. 19-32.

Benedek, J \& Bajtalan, H 2015, 'Recent regionalization discourses and projects in Romania with special focus on the Székelyland', Transylvanian Review of Administrative Sciences, vol. 11, no. 44, pp. 23-41.

Bochsler, D \& Szöcsik, E 2013, 'The forbidden fruit of federalism: Evidence from Romania and Slovakia', West European Politics, vol. 36, no. 2, pp. 426-446.

Brink, A 2004, 'The break-up of municipalities: Voting behavior in local referenda', Economics of Governance, vol. 5, no. 2, pp. 119-135.

Chen, P 2002, 'They're not like us: The de-amalgamation process of Delatite Shire', Paper proceedings of the Jubilee Conference of the Australian Political Science Association, Canberra, Australian National University. Available from <http://hdl.handle.net/11343/33707>. [28 March 2020].

Dobre, AM 2009, 'The dynamics of europeanisation and regionalisation: Regional reform in Romania', Perspectives on European Politics and Society, vol. 10, no. 2, pp. 181194.

Dollery, B, Kortt, M \& Grant, B 2011, 'A normative model for local government de-amalgamation in Australia', Australian Journal of Political Science, vol. 46, no. 4, pp. 601-615.

Drew, J \& Dollery, B 2014, 'Separation anxiety: an empirical evaluation of the Australian Sunshine Coast Regional Council de-amalgamation', Public Money \& Management, vol. 34, no. 3, pp. 213-220.

Drew, J, Razin, E \& Andrews, R 2019, 'Rhetoric in municipal amalgamations: a comparative analysis', Local Government Studies, vol. 45, no. 5, pp. 748-767.

Erlingsson, GÓ 2005, 'Modelling secessions from municipalities', Scandinavian Political Studies, vol. 28, no. 2, pp. 141-159.

Gheorghiță, A 2010, Lideri politici și construcția deciziei de vot [Political leaders and the construction of voting decisions], Institutul European, Iași.

Guvernul României [Government of Romania] 2001a, Hotărâre nr. 455 din 2001 privind aprobarea Planului de acţiune al
Programului de guvernare pe perioada 2001-2004 [Decision no. 455 from 2001 approving the Action Plan of the 20012004 Governing Programme]. Monitorul Oficial, No. 267, Part I.

Guvernul României [Government of Romania] 2001b, Hotărârea nr. 1006 din 2001 pentru aprobarea Strategiei Guvernului privind accelerarea reformei în administrația publică [Decision no. 1006 from 2001 approving the Government Strategy for the Acceleration of Public Administration Reform]. Monitorul Oficial, No. 660, Part I.

Guvernul României [Government of Romania] 2016, 'Participarea premierului Dacian Cioloș la cea de-a XIX-a sesiune ordinară a Adunării Generale a Asociaţiei Comunelor din România' [The participation of prime-minister Dacian Cioloș to the $\mathrm{XIX}^{\text {th }}$ meeting of the General Assembly of the Association of Communes from Romania]. Available from: <https:// gov.ro/ro/stiri/comunicat-de-presa-si-discurs-participareapremierului-dacian-ciolos-la-ev-asociatiei-comunelor-dinromania>. [28 March 2020].

Hsieh, H-F \& Shannon, SE 2005, 'Three approaches to qualitative content analysis', Qualitative Health Research, vol. 15, no. 9, pp. 1277-1288.

lordan, I \& Alexandrescu, V 1996, 'Consideraţii geografice privind reorganizarea administrativă a teritoriului României' ['Geogrpahical assessment on the administrative reorganisation of Romanian territory'], Revista Geografică, no. II-III, pp. 118-121.

Kopric, I 2012, 'Consolidation, fragmentation, and special statuses of local authorities in Europe', Croatian \& Comparative Public Administration, vol. 12, p. 1175-1196.

Lima, RC de A \& Silveira Neto, R da M 2018, 'Secession of municipalities and economies of scale: Evidence from Brazil', Journal of Regional Science, vol. 58, no. 1, pp. 159180.

Maxfield, E 2012, 'Resistance to change: Romania's debate over territorial reforms', Sfera Politicii, vol. 20, no. 167, pp. 12-20.

Miljan, LA \& Spicer, Z 2015, De-Amalgamation in Canada: Breaking up is hard to do, Fraser Institute. Available from: $<$ https://www. fraserinstitute.org/sites/default/files/deamalgamation-in-canada.pdf $>$. [28 March 2020].

Ministerul Agriculturii și Dezvoltării Rurale [Ministry of Agriculture and Rural Development] 2008, 'Programul Naţional de Dezvoltare Rurală 2007-2013' ['National Rural Development Programme 2007-2013']. Available from: <http://old.madr. ro/pages/dezvoltare_rurala/pndr_versiune_februarie_2008. pdf>. [28 March 2020]. 
Nistor, IS 2000, Comuna şi judeţul. Evoluţia istorică [The commune and the county. The historical evolution], Dacia, Cluj-Napoca.

O'Dwyer, C 2006, 'Reforming regional governance in East Central Europe: Europeanization or domestic politics as usual?', East European Politics \& Societies, vol. 20, no. 2, pp. 219-253.

Parlamentul României [Parliament of Romania] 2000, Program de guvernare din 28 decembrie 2000 pe perioada 20012004 [Governing Programme from December 28, 2000 for 2001-2004]. Monitorul Oficial, No. 700, Part I.

Parlamentul României [Parliament of Romania] 2001a, Lege nr. 215 din 23 aprilie 2001 a administraţiei publice locale [Law no. 215 from April 23, 2001 on local public administration]. Monitorul Oficial, No. 204, Part I.

Parlamentul României [Parliament of Romania] 2001b, Lege nr. 351 din 6 iulie 2001 privind aprobarea Planului de amenajare a teritoriului național - Secțiunea a IV-a Rețeaua de localități [Law no. 351 from July 6, 2001 approving the National Spatial Plan - Section IV the network of localities]. Monitorul Oficial, No. 408, Part I.

Preda, C 2013, 'Partide, voturi şi mandate la alegerile din România (1990-2012)' ['Parties, votes and seats in Romanian elections (1990-2012)'], Studia Politica. Romanian Political Science Review, vol. 13, no. 1, pp. 27-110.

Preda, C \& Soare, S 2008, Regimul, partidele și sistemul politic din România [The regime, the parties and the political system of Romania], Nemira, București.

Profiroiu, CM, Profiroiu, AG \& Szabo, SR 2017,'The decentralization process in Romania' in The Palgrave Handbook of Decentralisation in Europe, eds JM Ruano \& M Profiroiu, Springer, Cham, pp. 353-387.

Profiroiu, CM \& Profiroiu, AG 2006, 'Decentralization process in Romania', Transylvanian Review of Administrative Sciences, vol. 2, no. 16, pp. 115-123.

Săgeată, R 2011, 'Administrative reforms in Romania-between political reasons and geographical realities', Geograful/The geographer, vol. III, no. 1-2, pp. 3-26.

Săgeată, R 2012, 'Inter-communal cooperation and regional development: The case of Romania', Quaestiones Geographicae, vol. 31, no. 2, pp. 95-106.

Skaburskis, A 1992, 'Goals for restructuring local government boundaries: Canadian lessons', Environment and Planning C: Government and Policy, vol. 10, no. 2, pp. 159-172.

Soare, FS 2013, 'IICCMER - 45 de ani de la ultima reorganizarea administrativ-teritorială a României' ['IICCMER - 45 years since Romania's last administrative-territorial reorganisation'], IICCMER. Available from: <https://www. iiccr.ro/45-de-ani-de-la-ultima-reorganizarea-administrativteritoriala-a-romaniei/>. [28 March 2020].

de Souza, SV, Dollery, BE \& Kortt, MA 2015, 'De-Amalgamation in action: The Queensland experience', Public Management Review, vol. 17, no. 10, pp. 1403-1424.

Stănuș, C 2018,'The architecture of a complex system: The Oradea metropolitan area in Romania' in Inter-Municipal Cooperation in Europe: Institutions and Governance, eds F Teles \& P Swianiewicz, Springer, Cham, pp. 293-303.

Stănuş, C \& Pop, D 2011,'Romania' in The Second Tier of Local Government in Europe: Provinces, Counties, Départements and Landkreise in Comparison, eds $\mathrm{H}$ Heinelt \& X Bertrana , Routledge, London, pp. 223-241.

Ștefan, L, Grecu, R, Todor, A \& Cristescu, R 2004, 'Local elections 2004: a turning point in Romanian politics', Romanian Journal of Society and Politics, vol. 4, no. 2, pp. 66-126.
Steiner, R, Kaiser, C \& Eythórsson, GT 2016,'A comparative analysis of amalgamation reforms in selected European countries' in Local Public Sector Reforms in Times of Crisis: National Trajectories and International Comparisons, eds S Kuhlmann \& G Bouckaert, Palgrave Macmillan UK, London, pp. 23-42.

Swianiewicz, P 2010, 'If territorial fragmentation is a problem, is amalgamation a solution? An East European perspective', Local Government Studies, vol. 36, no. 2, pp. 183-203.

Swianiewicz, P 2018, 'If territorial fragmentation is a problem, is amalgamation a solution? - Ten years later', Local Government Studies, vol. 44, no. 1, pp. 1-10.

Swianiewicz, P 2021, 'From post-communist democratic laissezfair to prevention of territorial fragmentation: tightening rules of municipal splits in Central and Eastern Europe after 1990', Miscellanea Geographica - Regional Studies on Development, vol. 25, no. 1, pp. 5-17.

Swianiewicz, P \& Łukomska, J 2019, 'Is small beautiful? The quasi-experimental analysis of the impact of territorial fragmentation on costs in Polish local governments', Urban Affairs Review, vol. 55, no. 3, pp. 832-855.

Tanguay, GA \& Wihry, DF 2008, 'Voters' preferences regarding municipal consolidation: Evidence from the Quebec demerger referenda', Journal of Urban Affairs, vol. 30, no. 3, pp. 325-345.

Tavares, AF 2018, 'Municipal amalgamations and their effects: a literature review', Miscellanea Geographica, vol. 22, no. 1, pp. $5-15$.

Yoder, JA 2003, 'Decentralisation and regionalisation after communism: Administrative and territorial reform in Poland and the Czech Republic', Europe-Asia Studies, vol. 55, no. 2, pp. 263-286.

Ziarul de Iași 1998, 'LNJAD cere înființarea urgentă a județelor abuziv desființate' ['LNJAD demands the urgent reinstatement of abusively amalgamated counties'], Ziarul de lași 4 December. Available from: <https://www. ziaruldeiasi.ro/local/suceava/Injad-cere-infiintarea-urgentaa-judetelor-abuziv-desfiintate nil2t>. [28 March 2020]. 
MISCELLANEA GEOGRAPHICA - REGIONAL STUDIES ON DEVELOPMENT

Vol. $25 \cdot$ No. $1 \cdot 2021 \cdot$ pp. 62-70 • ISSN: 2084-6118 • DOI: 10.2478/mgrsd-2020-0044

Appendix. Map of local government splits/de-amalgamations in Romania, 1990-2019

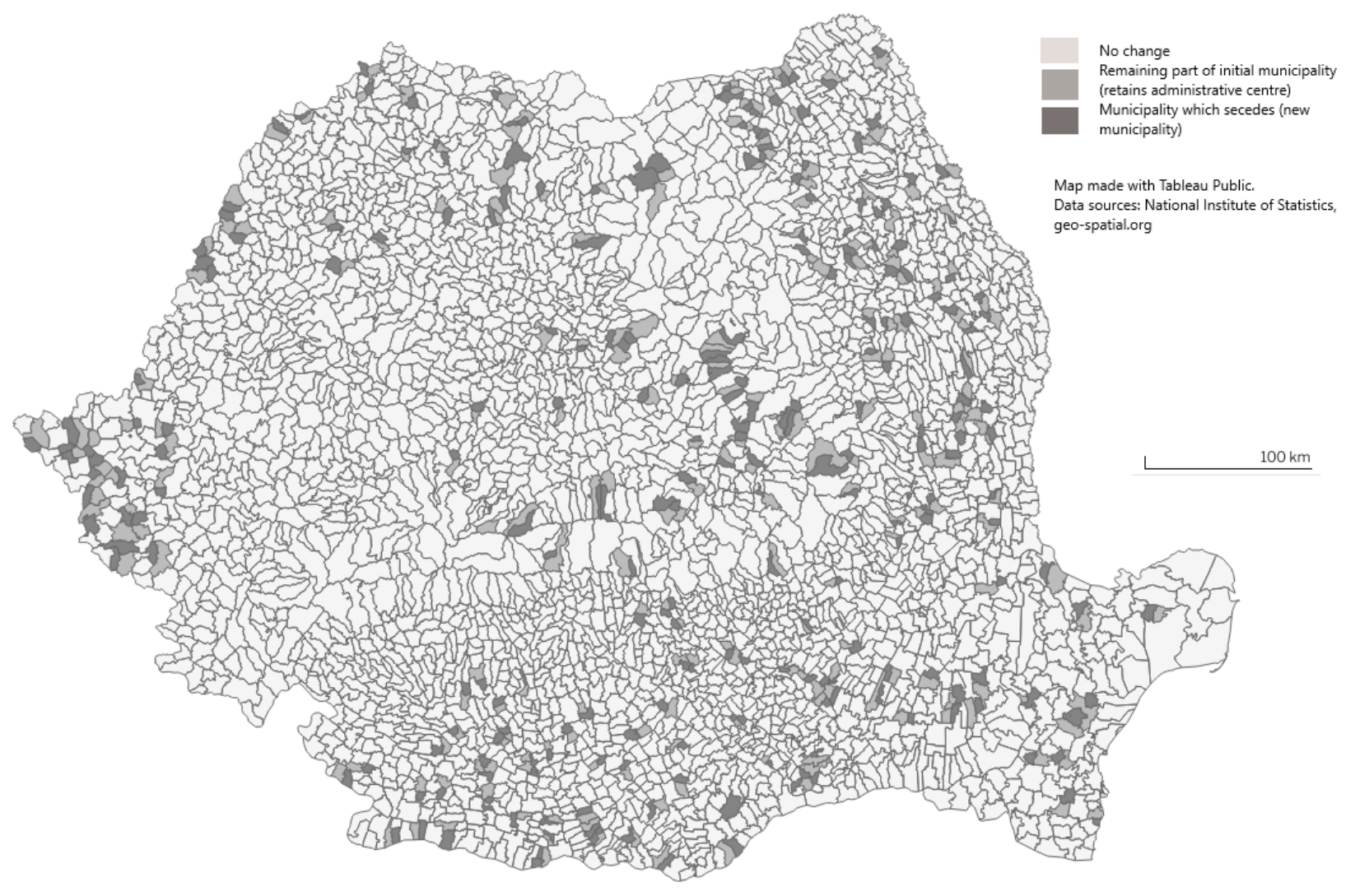

